\title{
Determines of Sectoral R\&D Investment in the UK: A Dymanic Panel Approach
}

\author{
M. Nusrate Aziz ${ }^{1}$, Muhammad S. Rahman ${ }^{1}$, Wan F. W. Yusoff ${ }^{1} \&$ Saiful A. Tareq ${ }^{2}$ \\ ${ }^{1}$ Graduate School of Management, Multimedia University, Cyberjaya, Malaysia \\ ${ }^{2}$ Middlesex University, London, UK \\ Correspondence: M. Nusrate Aziz, Graduate School of Management, Multimedia University,Cyberjaya 63100, \\ Malaysia. E-mail: nusrate@yahoo.com
}

Received: July 12, 2013 Accepted: August 5, 2013 Online Published: August 20, 2013

doi:10.5539/res.v5n4p135

URL: http://dx.doi.org/10.5539/res.v5n4p135

\begin{abstract}
The study estimates the determinants of R\&D expenditure in the UK by using sectoral data of eight large scale industries over time. We examined both traditional and exceptional however empirically plausible determinants of R\&D using two alternative dynamic models. Pooled OLS, the Fixed Effects and the Random Effects models are used for estimation. We find that the size of R\&D expenditure in the UK is smaller than many other industrial countries.. The largest amount of R\&D expenditure in the UK, takes place for 'machineries' industry followed by 'communication equipment' and 'post and telecommunication' industries. Estimated results demonstrate that the market size, ratio of skilled to unskilled workers, and macroeconomic policies significantly affect R\&D investment in the UK. Working hours of low, medium and high skilled workers' significantly affect the R\&D expenditure with different size effects. We also find that R\&D expenditure is an industry specific phenomenon.
\end{abstract}

Keywords: R\&D investment, dynamic panel

\section{Introduction}

Law of diminishing marginal returns suggests that marginal productivity of factors of production declines with an increased use of them. Romer (1986), however, shows that technology and externalities in knowledge (i.e., technology progress, research and development) prevents marginal product declining. Romer (1990) and Jones (1995) suggest that profit seeking firms must invest in research and development. Higher productivity in any sector of an economy requires positive technological change. A large number of existing literatures has developed theoretical models where the long-run rate of economic growth is assumed to be driven by the investments in R\&D activities. Romer (1990), Grossman and Helpman (1991) and Aghion and Howitt (1992), for example, explain the role of R\&D activities as the 'engine of economic growth'. Subsequently, technology has assumed to be no longer an exogenous variable in growth models; it rather can be endogenized by investing in R\&D. In micro context, innovation is the result of firms' endeavour to produce improved or/and new products, increase productivity, change organisational arrangements, and introduce new designing and marketing processes. Undoubtedly, innovations come through research and development.

There is an extensive body of empirical literature, which supports the theoretical prediction that R\&D investment has positive and significant effect on economic growth at aggregate (overall economy) and disaggregate (industry) levels.However, the size and significance vary within and across countries. For instance, Guellec and Pottelsberghe (2001) reveal that a one percent increase in the business sector R\&D stock can influence the growth of multifactor productivity by 0.13 percent. Similarly, Becker and Pain (2003) find that investment in R\&D positively affects the economic growth both within the country and across countries. Jalava (2003) finds that overall decline in labour productivity in Finnish industries from 1975 to 2001 was because the Finnish economy had neither employed enough human capital nor invested in information and communication technology (ICT). Dilling-Hansen et al. (1998) show that Danish industrial productivity has increased significantly in the 1990s due to a large amount of investment in R\&D sector. We, therefore, can conclude that R\&D investment significantly effects the productivity growth of business and economy.

A growing body of theoretical and empirical literatures has been investigating the determinants of R\&D expenditure (Vecchi, et al, 2007; Harmantzis and Tanguturi, 2005; Griffiths and Webster, 2004; Becker and Pain, 
2003; Lee and Hwang, 2003; Bhagat and Welch, 1995; Waterson and Lopez, 1983; Nadiri, 1979; Grabowski, 1968; Mansfield, 1964). With a huge discrepancy in findings, these literatures suggest that the sales and profitability, product market competition, the interest rates, the exchange rate, skilled labour, and composition of R\&D expenditure are significant determinants of $R \& D$ expenditure. Some literatures indicate that country specific phenomena could be very influential in determining R\&D expenditure. However, there is no consensus about a specific set of significant determinants of $R \& D$ investment as yet. Rather, the debate regarding this issue has been growing markedly.

In recent years, $R \& D$ expenditure has been increasing significantly in both developed and developing countries. Developed countries have been spending more than developing countries in R\&D sector. As a result, generally, human capital and productivity of factors in developed countries is found much higher than developing countries (Griffith, Redding and Reenen, 2004). Developed countries, consistently, have been increasing their R\&D expenditure in high-tech industries (Griliches, 1980; Adams and Jaffe, 1996; Goto and Suzuki, 1989; Hall, 1993). However, there is noticeable dissimilarities exists in terms of R\&D expenditure among developed countries too. Figure 1 shows the R\&D expenditure in major six developed countries over time.

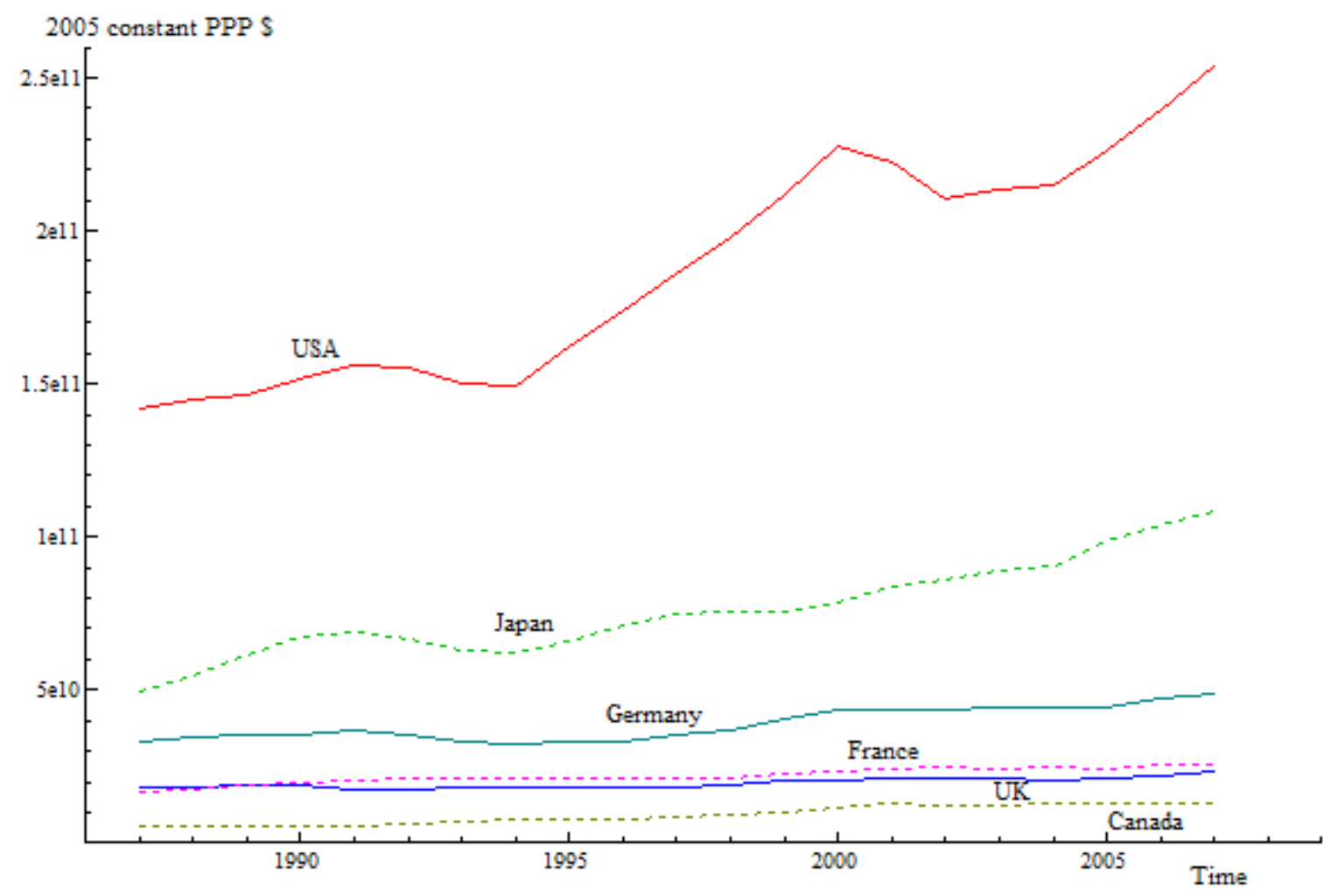

Figure 1. R\&D Investments in the USA, Japan, Germany, France, UK and Canada

Data Source: OECD ANDBERD data set

Some industries generally require large amount of investment in R\&D (such as, space science) compared to other industries (such as, food sector). Some industries get special priority in some countries (but not other countries) in terms of R\&D investment. Some investors employ capital intensive technology, however, others employ labour intensive technology in production. Some industries are service oriented; however, some others are product oriented. Consequently, this is not surprisingly that there is a large discrepancy in R\&D investment between sectors and between countries. R\&D investment, therefore, could be a country and a commodity specific phenomenon. The UK is one of the major R\&D investors in the world. However, across industries in the UK there is a big discrepancy in R\&D investment (Figure 2). Public investment in R\&D of the UK has gradually been falling while private investment has been growing rapidly ( Figure 3, in Appendix). Sector-wise R\&D investment over time by eight major industries in the UK is presented in Figure 2. 


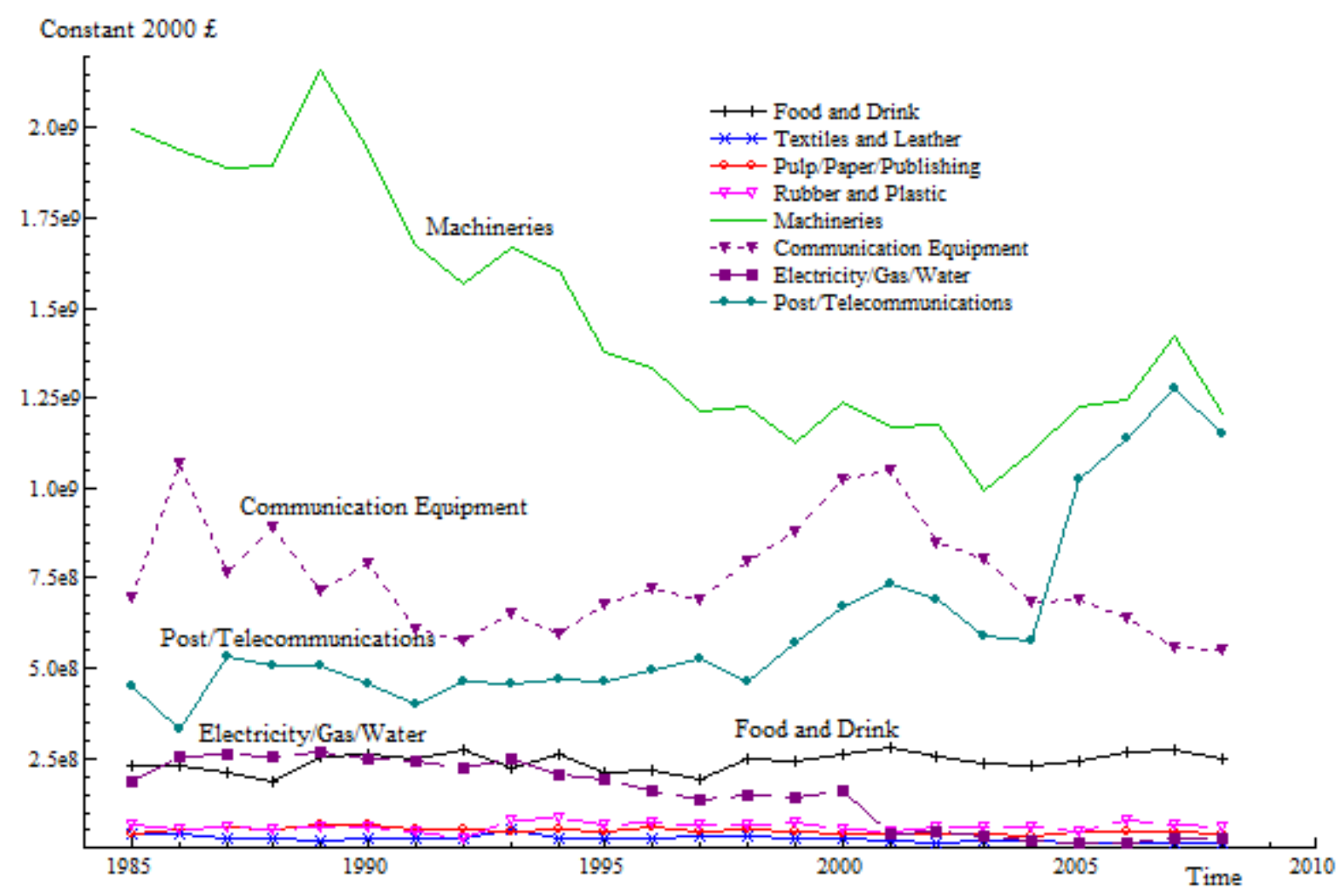

Figure 2. R\&D Investments in different industries in the UK over time

Data Source: Office for National Statistics, UK

Figure 2 indicates that R\&D expenditure has been falling in most of the industries in the UK over time, where the Post/telecommunications industry is found to be the only exception. Vecchi et al. (2007) also support this finding. Vecchi et al. state that:

"....the UK could not improve its overall performance between 1993 and the end of the decade after a more pronounced and longer-lasting decline in the earlier years of the decade".

Consequently, the reasons for the downward trend of R\&D investment in the UK are needed to be investigated. Existing literatures assumes that the market size, sources of funding, number of scientists and engineers, and macroeconomic variables such as exchange rate, interest rate are significant determinants of R\&D expenditure. However, some other potential determinants of R\&D investment, such as, share of ICT and non-ICT service in a particular industry, and share of high, medium and low skilled employees' working hours, have not been investigate in the literature as yet. This study examines both traditional and potential determinants of R\&D investment in the UK.

Subsequently, the specific objectives of this study in to investigate: (i) whether traditionally examined determinants of R\&D investment are still significant in UK industries; (ii) whether R\&D investment depends on the amount of ICT and non-ICT capital; (iii) whether relative working hours of different skilled (high skilled, medium skilled and low skilled) employees influence R\&D investments differently; (iv) whether the R\&D expenditure is an industry specific phenomenon.

The rest of the paper is structured as follows. Section 2 reviews existing literature; Section 3 presents the data, model and methodology; Section 4 estimates the models and discuss the findings emerged from estimation; and 5 concludes the study.

\section{The Literature}

Existing literature on R\&D expenditure can be classified into two major groups - first, literatures which investigate the determinants of R\&D expenditure, and secondly, literatures which evaluate the performance of R\&D towards economic growth. The earlier group of literature examines either the industrial variability 
in $R \& D$ expenditure or the impact of economic and financial incidence on $R \& D$ investment. While the latter group estimate the impact of R\&D on economic growth.

There is yet a third group of studies which indicates that determinants of R\&D investment have been a time variant phenomenon. For example, if some determinants are found to be significant in this decade, they may not be significant determinants for the next decade.

Waterson and Lopez (1983), Backer and Pain (2003) and Vecchi et al. (2007) have examined the significant factors which determine R\&D expenditure in the UK in the 1970s and 1990s. The earliest paper finds that firm size and concentrated market structure do not significantly affect the R\&D expenditure in the 1970s. However, the R\&D expenditure was found to be industry specific (for instance, the aerospace industry spent heavily on R\&D) in the same decade. In the 1990s, the sales and profitability, product market competition, the interest rates, the exchange rate and skilled labour are found to be significant determinants of R\&D expenditure in the UK (Backer and Pain, 2003).

Sources of $R \& D$ expenditure and sector-wise requirements of $R \& D$ funds have also been found as significant determinants of R\&D investment. Vecchi et al. (2007) find that due to lower R\&D funding by the government in the 1990s, there was a significant fall in R\&D expenditure in the military sector and the business enterprises in the UK. However, the study evident a significant spillover effect from research in higher education sector to Low-Tech industries in the UK and Germany in the 1990s. The foreign affiliates were positively associated with the total R\&D expenditure in the UK. Gustavsson and Poldahl (2003) find that $R \& D$ investment is positively related with $R \& D$-intensity of other firms within the same concern. Guellec and Ioannidis (1997) find that government investment and structural shift from high-tech industries to service industries are significant determinants of R\&D expenditures in business. Government funding and shift to service sector are also found as significant determinants of R\&D investments in the US and the UK. However, the contributions vary across countries.

The growth of R\&D investment depends on whether respective countries/industries have a traditional practice in investing for $R \& D$. Subsequently, lagged $R \& D$ investment could also be an important factor for current R\&D expenditure. Nadiri (1979) finds that current R\&D expenditure depends on earlier investment in R\&D and current capital stock of firms. Lee (2003) also indicates that previously accumulated technological knowledge of firm is positively related to R\&D investment. Griffiths and Webster (2010) suggest that lag of R\&D activities, lag of firm's growth rate and past profits are significant determinants for current R\&D investment.

$R \& D$ expenditure may an industry specific phenomenon, too. Griffiths and Webster (2004) find that R\&D expenditure is highly firm specific; and the $R \& D$ investment also depends on how aggressive and intuitive are the managers towards spending in $R \& D$. Wang (2010) finds that tertiary education and the proportion of scientific researchers are positive determinants of $R \& D$ intensity.

Availability of funds and prospect of business have also been found as significant determinants of R\&D expenditure. Griffiths and Webster (2004) indicate that if the debt ratio of enterprise in previous year is lower, the R\&D expenditure becomes higher this year. Malmberg (2008) suggests that the 'past cash flow' has a significant influence on current R\&D expenditure. This finding is similar to the finding for the US pharmaceutical industry. However, Mahlich and Roediger-Schluga (2006) find an insignificant impact of 'cash flow' on R\&D expenditure. Mansfield (1964) suggests that firm size, growth potential, government subsidy and R\&D promotion policies have positive impact while dividends (internal cash flow) have negative effect on $R \& D$ expenditure.

The existing literature, therefore, in general, indicates that lag of R\&D expenditure, firm size, market size, profitability or growth potential, competitiveness, stock of capital, industry specific requirements are the basic factors which determines R\&D expenditure. However, it seems that there are significant variations in terms of findings across literature. Especially, we observe that the findings vary markedly across the literature on the UK.

\section{Data, Model and Methodology}

The study uses industry level annual data for (i) Food, beverages and tobacco; (ii) Textiles, textile products, leather and footwear; (iii) Pulp, paper, paper products, printing and publishing; (iv) Rubber and plastics products; (v) Machineries; (vi) Communication equipment; (vii) Electricity, gas and water supply; and (viii) Post and telecommunications of the UK from 1985 to 2005. Data are sourced from different datasets including the Office of 
National Statistics (ONS) of the UK, the EU KLEMS Growth and Productivity accounts, EPKE dataset and the world development Indicators (WDI) of the World Bank.

The study employs a multivariate dynamic regression approach using panel data. We estimate two models. Model (1) includes traditional determinants while Model (2) includes some new potential determinants of R\&D investment in addition to the tradinal determinants. All variables are in real term. The empirical Model (1) is as follows:

$$
\begin{gathered}
\Delta \ln R_{i t}=\beta_{i}+\beta_{1} \ln R_{i, t-1}+\beta_{2} \ln Y_{i, t-1}+\beta_{3} \ln G_{i, t-1}+\beta_{4} \ln F_{i, t-1}+\beta_{5} \ln S E_{i, t-1}+\beta_{6} \ln E_{t}+\beta_{7} I_{t}+\beta_{j} D U M_{i} \\
+\varepsilon_{i t}
\end{gathered}
$$

where, $R_{i t}$ is real $\mathrm{R} \& \mathrm{D}$ expenditure of $i t h$ industry at time $t ; Y$ is market size which is proxied by the industrial output index; $G$ is the proportion of R\&D expenditure by government; $F$ is proportion of R\&D expenditure by foreign owned firms; $S E$ is ratio of number of scientists and engineers and total number of employees in the industry; $E$ is real effective exchange rate index; $I$ is real interest rate; and $D U M_{i}$ is industry specific dummy variable.

An alternative model is also applied to test: (i) whether share of ICT and non-ICT capital can make any significant difference in R\&D investments; and (ii) whether working hours of high skilled, medium skilled and low skilled employees influence $\mathrm{R} \& \mathrm{D}$ investments differently. The alternative model is as follows:

$$
\begin{aligned}
\Delta \ln R_{i t}=\beta_{i}+\beta_{1} & \ln R_{i, t-1}+\beta_{2} \ln Y_{i, t-1}+\beta_{3} G_{i, t-1}+\beta_{4} F_{i, t-1}+\beta_{5} S E_{i, t-1}+\beta_{6} \ln E_{t}+\beta_{7} I_{t}+\beta_{8} \ln I C T_{i, t-1} \\
& +\beta_{9} \ln N I C T_{i, t-1}+\beta_{10} \ln H_{i, t-1}+\beta_{11} \ln M_{i, t-1}+\beta_{12} \ln L_{i, t-1}+\beta_{j} D U M_{i} \\
& +\varepsilon_{i t}
\end{aligned}
$$

where, ICT is ICT capital service index in the business; NICT is non-ICT capital service index in the business; $\mathrm{H}$ is proportion of working hour of high skilled workers in the industry; $\mathrm{M}$ is proportion of working hour of medium skilled workers; and $\mathrm{L}$ is proportion of working hour of low skilled workers.

Data for R\&D expenditure are collected from the EUKLEMS database (released in March 2008), Office for National Statistics, UK. The measure for the number of scientists and engineers in the industry relative to total employees are collected from the Office for National Statistics (rdbd4). The UK government expenditure in R\&D and overseas firms expenditure in UK R\&D come from the Office for National Statistics, (rdbd3). Industrial value added index is collected from EUKLEMS database (release in March 2008). ICT and Non-ICT capital services as well as hours worked by high-skilled, medium-skilled and low-skilled people engaged (share in total hours) are also collected from EUKLEMS database (release in March 2008). Real interest rate and real effective exchange rate index are found in the country table in WDI (edition: April 2010) of the World Bank.

The study subsequently estimates the empirical models using three different estimation techniques: pooled OLS (POLS) with country specific intercept, the fixed effects (FE) model and the random effects (RE) model. Finally, the Hausman test is used to select the most appropriate model. Estimated results of all three models, however, are reported in the test.

The first difference of industry level $R \& D$ expenditure, which stands for the growth in $R \& D$ expenditure, is employed as the dependent variable. First lag of dependent variable, first lag of market size, first lag of the number of scientists and engineers as a ratio of total employment, and first lag of internal government funds and overseas funds in R\&D are used in the empirical model. Existing literature (Becker \& Pain, 2003; Vecchi et al., 2007) indicate that not the current value but the lag of the variables may affect the R\&D expenditure growth. This is because the impact of employed variables in the model is less likely to be felt by R\&D investment, immediately. Consequently, the estimated empirical model has become a dynamic model in our study. It is also rational to assume that current exchange rate and current interest rates (not lags) may affect the R\&D expenditure. Hence, similar to Becker and Pain (2003) we use current exchange rate and current interest rate as the determinants of R\&D.

We also assume that the R\&D expenditure of this year, for example, would depend on how much ICT and non-ICT capital service have been taken place in the last year. Similarly, how many hours are worked by the high-mediumand low-skilled workers in last year would influence the R\&D investment of this year. Consequently, in Model (2), we employ lag of five additional variables namely, ICT and non-ICT capital service, and high-medium- and low-skilled workers working hours. It is worth mentioning that this is uniqueness of our study.

The study uses industry specific dummy variables assuming that $R \& D$ investments may be different in different industries. We know that FE model captures industry specific heterogeneity. However, although POLS assume a common constant for all industries, we use cross-sectional dummies to capture different intercepts in 
cross-sectional heterogeneity. Seven cross-sectional dummies are included in the model for eight industries to avoid the 'dummy variable trap'. Value of dummy is given 1 (one) for the observed industry, and the value is 0 (zero) otherwise.

\section{Estimation}

A descriptive statistic of variables shows the basic feature of data which is presented in Table 1. It is worth noting that data for the share of ICT and non-ICT R\&D expenditure and working hours by different skill level of labours are available from only 1985 to 2005 and we use a strongly balanced panel estimation by using same timeframe for all variables. The average $R \& D$ expenditure for the 'machineries industry' is $£ 147$ million a year which is the highest average expenditure among major 8 industries in the UK. The second largest R\&D expenditure takes place for the communication equipment industry. Industry specific mean, standard deviation, minimum and maximum expenditures are also presented in Table 1 .

Table 1. Descriptive statistics

\begin{tabular}{|c|c|c|c|c|c|}
\hline Variable & Observation & Mean & Std. Dev. & Min & Max \\
\hline Real R\&D & 168 & $4.19 \mathrm{e}+08$ & $5.01 \mathrm{e}+08$ & $1.32 \mathrm{e}+07$ & $2.16 \mathrm{e}+09$ \\
\hline Market Size & 168 & 102.66 & 32.98 & 56 & 274.8 \\
\hline Scientist and Engineers ratio & 168 & 0.55 & 0.06 & 0.47 & 0.64 \\
\hline Share of Govt. fund & 168 & 0.12 & 0.05 & 0.07 & 0.23 \\
\hline Share of Overseas fund & 168 & 0.19 & 0.06 & 0.11 & 0.30 \\
\hline High skilled share (hrs.) & 168 & 8.50 & 4.29 & 2.2 & 21.4 \\
\hline Medium skilled share (hrs.) & 168 & 66.77 & 7.02 & 48.9 & 77.1 \\
\hline Low skilled share (hrs.) & 168 & 24.72 & 10.52 & 5.8 & 48.6 \\
\hline ICT service & 168 & 138.06 & 113.58 & 12.7 & 554.4 \\
\hline Non-ICT service & 168 & 98.81 & 11.49 & 65.9 & 120 \\
\hline REER & 168 & 88.00 & 8.63 & 76.02 & 100.27 \\
\hline Real Interest Rate & 168 & 3.91 & 1.75 & 0.61 & 7.17 \\
\hline
\end{tabular}

The next step is to choose the most appropriate estimation method. POLS regression method assumes that intercepts and slope coefficients do not vary across cross-sections and time periods. However, we separately uses cross sectional dummy variables to capture cross-sectional heterogeneity. Hence, our estimated POLS model can be written as follows:

$$
Y_{i t}=\alpha+\beta_{i t} X_{i t}+D_{i}+\varepsilon_{i t}
$$

where, $\mathrm{Y}$ is dependent, $\mathrm{X}$ is vector of explanatory variables, $\mathrm{D}$ is industry specific dummy variables, $\mathrm{i}=$ $(1,2,3 \ldots \ldots . . . .8), t=(1985,1986,1987 \ldots \ldots 2005)$ and $\varepsilon$ is error term.

FE model allows different constants for each cross-section. This type of model is also known as the least squares dummy variable (LSDV) since it involves dummy variables in order to capture the cross-sectional heterogeneity. Our FE model can be presented as follows:

$$
Y_{i t}=\alpha_{i}+\beta_{i t} X_{i t}+\varepsilon_{i t}
$$

There is yet another alternative panel estimation technique, RE model which we employ in our study. Basic difference between FE and RE model is that the latter model assumes that intercept for each cross-section is not fixed. Rather, they are random parameters. RE model can be written as:

$$
\begin{aligned}
& Y_{i t}=\left(a+v_{i}\right)+\beta_{i t} X_{i t}+\varepsilon_{i t} \\
& Y_{i t}=a+\beta_{i t} X_{i t}+\left(v_{i}+\varepsilon_{i t}\right)
\end{aligned}
$$

The variability of constant term is allowed within each cross-section in RE model. The intercept can therefore be written as:

$$
\alpha_{i}=a+v_{i}
$$

where, $v_{i}$ is a standard random variable with zero mean.

We subsequently derive a 'General-to-Specific' model by deleting the insignificant variables and insignificant lags, sequentially. Estimated results are presented in Table 2: 
Table 2. Panel estimation

\begin{tabular}{|c|c|c|c|c|c|c|}
\hline & & Model 1 & & & Model 2 & \\
\hline & $\begin{array}{c}\text { Pooled } \\
\text { OLS }\end{array}$ & $\begin{array}{c}\text { Random } \\
\text { Effect }\end{array}$ & $\begin{array}{l}\text { Fixed } \\
\text { Effect }\end{array}$ & $\begin{array}{l}\text { Pooled } \\
\text { OLS }\end{array}$ & $\begin{array}{c}\text { Random } \\
\text { Effect }\end{array}$ & $\begin{array}{l}\text { Fixed } \\
\text { Effect }\end{array}$ \\
\hline Constant & $\begin{array}{c}14.79 * * * \\
(1.52)\end{array}$ & $\begin{array}{c}8.06^{* * *} \\
(2.00)\end{array}$ & $\begin{array}{c}15.55 * * * \\
(1.55)\end{array}$ & $\begin{array}{l}4.15^{*} \\
(2.24)\end{array}$ & $\begin{array}{c}10.13 * * * \\
(2.24)\end{array}$ & $\begin{array}{c}5.14 * * \\
(2.23)\end{array}$ \\
\hline $\ln R_{i, t-1}$ & $\begin{array}{c}-0.69 * * * \\
(0.05)\end{array}$ & $\begin{array}{c}-0.23 * * * \\
(0.04)\end{array}$ & $\begin{array}{c}-0.69 * * * \\
(0.05)\end{array}$ & $\begin{array}{c}-0.79 * * * \\
(0.05)\end{array}$ & $\begin{array}{c}-0.25^{* * *} \\
(0.04)\end{array}$ & $\begin{array}{c}-0.79 * * * \\
(0.05)\end{array}$ \\
\hline $\ln Y_{i, t-1}$ & $\begin{array}{l}0.22^{*} \\
(0.12)\end{array}$ & - & $\begin{array}{l}0.22 * \\
(0.12)\end{array}$ & $\begin{array}{c}0.36^{* * *} \\
(0.14)\end{array}$ & - & $\begin{array}{c}0.36^{* *} \\
(0.14)\end{array}$ \\
\hline$S E_{i, t-1}$ & - & $\begin{array}{l}1.80 * * \\
(0.81)\end{array}$ & - & - & - & - \\
\hline $\ln E_{t}$ & $\begin{array}{c}-0.81 * * * \\
(0.28)\end{array}$ & $\begin{array}{c}-1.07 * * \\
(0.46)\end{array}$ & $\begin{array}{c}-0.81 * * * \\
(0.28)\end{array}$ & - & $\begin{array}{c}-1.04 * * \\
(0.43)\end{array}$ & - \\
\hline$I_{t}$ & $\begin{array}{c}0.12 * * * \\
(0.04)\end{array}$ & $\begin{array}{l}0.11^{*} \\
(0.06)\end{array}$ & $\begin{array}{c}0.12 * * * \\
(0.04)\end{array}$ & $\begin{array}{c}0.14 * * * \\
(0.04)\end{array}$ & $\begin{array}{c}0.13^{* *} \\
(0.06)\end{array}$ & $\begin{array}{c}0.14^{* * * *} \\
(0.04)\end{array}$ \\
\hline $\ln I C T_{i, t-1}$ & - & - & - & $\begin{array}{c}-0.17 * * \\
(0.07)\end{array}$ & - & $\begin{array}{c}-0.17 * * \\
(0.08)\end{array}$ \\
\hline $\ln H_{i, t-1}$ & - & - & - & $\begin{array}{c}0.85^{* * *} \\
(0.16)\end{array}$ & - & $\begin{array}{c}0.85^{* * * *} \\
(0.16)\end{array}$ \\
\hline $\ln M_{i, t-1}$ & - & - & - & $\begin{array}{l}1.00^{* *} \\
(0.50)\end{array}$ & - & $\begin{array}{l}1.00^{* *} \\
(0.50)\end{array}$ \\
\hline $\ln L_{i, t-1}$ & - & - & - & $\begin{array}{c}0.94 * * * \\
(0.18)\end{array}$ & $\begin{array}{c}-0.29 * * \\
(0.11)\end{array}$ & $\begin{array}{c}0.94 * * * \\
(0.18)\end{array}$ \\
\hline$D_{\text {Food }}$ & $\begin{array}{c}0.94 * * * \\
(0.12)\end{array}$ & - & - & $\begin{array}{c}1.32 * * * \\
(0.14)\end{array}$ & - & - \\
\hline$D_{\text {Textile }}$ & $\begin{array}{c}-0.58 * * * \\
(0.10)\end{array}$ & - & - & $\begin{array}{c}-0.43 * * * \\
(0.13)\end{array}$ & - & - \\
\hline$D_{\text {Pulp }}$ & $-0.13(0.10)$ & - & - & $\begin{array}{c}-0.19^{* *} \\
(0.09)\end{array}$ & - & - \\
\hline$D_{\text {Post }}$ & $\begin{array}{c}1.51^{* * *} \\
(0.13)\end{array}$ & - & - & $\begin{array}{c}2.04^{* * *} \\
(0.15)\end{array}$ & - & - \\
\hline$D_{\text {Machine }}$ & $\begin{array}{c}2.23 * * * \\
(0.17)\end{array}$ & - & - & $\begin{array}{c}2.58 * * * \\
(0.17)\end{array}$ & - & - \\
\hline$D_{\text {Commequip }}$ & $\begin{array}{c}1.71 * * * \\
(0.15)\end{array}$ & - & - & $\begin{array}{c}2.02 * * * \\
(0.15)\end{array}$ & - & - \\
\hline$D_{\text {Electric }}$ & $\begin{array}{c}0.43 * * * \\
(0.10) \\
\end{array}$ & - & - & $\begin{array}{c}0.58 * * * \\
(0.16) \\
\end{array}$ & - & - \\
\hline No. of Obs & 167 & 167 & 167 & 167 & 167 & 167 \\
\hline Adj $R^{2}$ & 0.60 & - & - & 0.67 & - & - \\
\hline F-stat/Wald $\chi^{2}$ & $23.48 * * *$ & $45.99 * * *$ & $58.07 * * *$ & $24.62 * * *$ & $51.69^{* * *}$ & $44.78 * * *$ \\
\hline Hausman Test & - & $367.56^{* * *}$ & - & - & $314.08^{* * *}$ & - \\
\hline
\end{tabular}

Note: Standard errors are in parenthesis. ${ }^{* *},{ }^{* *}$ and $*$ show significance at $1 \%, 5 \%$ and $10 \%$. 
POLS results (for Model 1) indicate that lagged R\&D expenditure, market size, real effective exchange rate and real interest rate significantly affect $R \& D$ investment growth. It is also found that $R \& D$ expenditure significantly varies across industries. The 'Machineries industry' of the UK requires the largest amount of R\&D investments followed by the 'communication equipment', the 'post and telecommunications', the 'food, beverages and tobacco', and the 'electricity, gas and water supply' industries. R\&D investment in the 'pulp, paper, paper products, printing and publishing' industry is found to be insignificant. The Hausman test, which rejects the null hypothesis, indicates that FE model is the most appropriate method for our panel data. Similar to POLS, the FE model depicts that lag R\&D expenditure, market size, real effective exchange rate and real interest rate are significant determinants for the growth of R\&D investment in the UK.

Estimated results of Model 2 (both POLS and FE) indicate that lag of R\&D expenditure, market size, real interest rate, ICT investments and lag of skilled level of workers are significant determinants of R\&D expenditure growth. Similar to Model 1, industry specific significant heterogeneity are alos found in Model 2. Market size and real interest rate are found to be positively correlated with $R \& D$ expenditure growth. Similar to the Model 1, the Hausman test rejects RE in Model 2. Thus, FE model seems to be the most appropriate estimator for Model 2 as well. The results of FE model are in accordance with the findings of POLS.

Industry specific dummies are found to be significant with different size effect in both Model 1 and Model 2, which indicate that $R \& D$ investment is an industry specific phenomenon. $R \& D$ investment is found to be significantly higher for the machineries, the post and telecommunications, the communication equipments, and the food, beverages and tobacco industries than other industries. These findings support the Figure 2 which shows the industry specific R\&D expenditure in the UK.

Growth in R\&D expenditure for low skilled workers significantly increases with the increase of low skilled workers' working hours. This indicates that firms' spend a significant amount on training and workshop for low skilled workers. Growth in R\&D expenditure increases with the increase in working hours for high-skilled and medium-skilled workers as well. However, the magnitude is higher for low and medium skilled workers than high skilled workers. It is worth recalling that the study uses lag of skilled level in empirical models. Thus, it seems that UK businesses invest more for previously low-skilled workers to improve their skills at appropriate level. Surprisingly, lagged ICT capital service is found to be negative and significant while lagged non-ICT capital service is found to be insignificant determinant of $R \& D$ expenditure growth.

\section{Conclusion}

The study estimates the determinants of R\&D expenditure growth in UK business. Two different dynamic models are estimated using industry level data of eight major industries in the UK for the period from 1985 to 2005. Although empirical Model 1 is commonly used in the existing literature, however, Model 2 is unique in this study. Higher adjusted $R^{2}$ in Model 2 indicates that additional variables worth including in empirical R\&D model. The study specifically attempts to examine whether lag $R \& D$ investment, market size, sources of R\&D funds, share of skilled employees compare to unskilled employees, real exchange rate, real interest rate, skilled level of workers, investment in ICT and non-ICT industries significantly affect the R\&D expenditure in the UK. Industry specific heterogeneous effects have also been tested. Three different estimators, pooled OLS, the Fixed Effects and the Random Effects models are used in the study.

Estimated results demonstrate that R\&D investment history, market size, ratio of skilled to unskilled workers in the industry, macroeconomic policy (e.g., the exchange rate, the interest rate), workers skills and their working hours are significant determinants for R\&D expenditure growth in the UK industries. The market size and real interest rate positively and significantly influence the $R \& D$ investments. $R \& D$ expenditures are also found to be an industry specific phenomenon in the UK. R\&D expenditure is found to be significantly higher in the 'machineries', the 'post and telecommunication', and the 'communication equipment' industries. The sign and significance level of lagged R\&D expenditure, market size and real interest rate are found to be consistent with Vecchi et al. (2007).

Estimated results also demonstrate that R\&D expenditure increases with the increase in working hours of high-skilled, medium-skilled and low-skilled workers; however, the magnitude is higher for low and medium skilled workers compared to high skilled worker. This indicates that UK firms' spend a significant amount on training and workshop for relatively low skilled workers.

\section{References}

Adams, J. D., \& Jaffe, A. B. (1996). Bounding the effects of R\&D: An investigation using matched establishment-firm data. Rand Journal of Economics, 27, 700-721. http://dx.doi.org/10.2307/2555878 
Aghion, P., \& Howitt, P. (1992). A model of growth through creative destruction. Econometrica, 60(2), 323-351. http://dx.doi.org/10.2307/2951599

Becker, B., \& Pain, N. (2003). What Determines Industrial R\&D Expenditure in the UK?. NIESR Working Paper 211.

Bhagat, S., \& Welch, I. (1995). Corporate research \& development investments International comparisons. Journal of Accounting and Economics, 19, 443-470. http://dx.doi.org/10.1016/0165-4101(94)00391-H

Dilling-Hansen M., Eriksson T., Madsen E. S., \& Smith V. (1998). Market Structure, Publicly and Privately Financed R\&D Spending. Empirical Evidence for Denmark Discussion Paper 1998:20, Centre for Industrial Economics, University of Copenhagen, 1998.

Goto, A., \& Suzuki, K. (1989). R\&D Capital, Rate of Return on R\&D Investment and Spillover of R\&D in Japanee Manufacturing Industries. The Review of Economics and Statistics, 71(4), 555-564. http://dx.doi.org/10.2307/1928096

Grabowski, H. G. (1968). The Determinants of Industrial Research and Development: A Study of the Chemical, Drug, and Petroleum Industries. The Journal of Political Economy, 76(2), 292-306. http://dx.doi.org/10.1086/259401

Griffith R., Redding S., \& Reenen, J. V. (2004). Mapping the two faces of R\&D: productivity growth in a panel of OECD industries. The Review of Economics and Statistics, 86(4), 883-895. http://dx.doi.org/10.1162/0034653043125194

Griffiths W., \& Webster E. (2004). The Determinants of Research and Development and Intellectual Property Usage among Australian Companies. Melbourne Institute Working Paper No. 27/04. http://dx.doi.org/10.1016/j.technovation.2010.03.005

Griffiths W., \& Webster E. (2010). What governs firm-level R\&D: Internal or external factors?. Technovation, 30, 471-481.

Griliches, Z. (1980). R\&D and productivity slowdown. American Economic Review, 70(1), 343-348.

Grossman, G. M., \& Helpman, E. (1991). Innovation and Growth in the Global Economy. MIT Press.

Guellec D., \& Ioannidis E. (1997). Causes of Fluctuations in R\&D Expenditures - A Quantitative Analysis. OECD Economic Studies, No. 29, 1997/II.

Guellec D., \& Pottelsberge B. (2001). R\&D and Productivity Growth: Panel Data Analysis of 16 OECD Countries. OECD Economic Studies (pp. 103-126). http://dx.doi.org/10.1787/652870318341

Gustavsson, P., \& Poldahl A. (2003). Determinants of Firm R\&D: Evidence from Swedish Firm Level Data. FIEF Working Paper Series 2003, No. 190.

Hall, B. H. (1993). R\&D Tax Policy During the 1980s: Success or Failure?. NBER Chapters. Tax Policy and the Economy (Vol. 7, pp. 1-36). National Bureau of Economic Research, Inc.

Harmantzis, F. C., \& Tanguturi V. P. (2005). Key Determinants of R\&D Expenditures in the US Telecommunications Equipment Industry. Working Paper, Stevens Institute of Technology, School of Management, Castle Point on the Hudson, Hoboken, NJ 07030, USA.

Jalava, J. (2003). Electrifying and Digitalizing the Finish Manufacturing Industry: Historic Notes of Diffusion and Productivity. The Research Institute of the Finnish Economy, Discussion Papers 870.

Jones, C. I. (1995). R\&D-Based Models of Economic Growth. Journal of Political Economy, 103, 759-784. http://dx.doi.org/10.1086/262002

Lee, C. (2003). A Simple Theory and Evidence on the Determinants of Firm R\&D'. Economic Innovation New Technology, 12(5), 385-395. http://dx.doi.org/10.1080/1043859022000003418

Lee, M., \& Hwang I. J. (2003). Determinants of Corporate R\&D Investment: An Empirical Study Comparing Korea's IT Industry with Its Non-IT Industry. ETRI Journal, 25(4). http://dx.doi.org/10.4218/etrij.03.0101.0401

Mahlich, J., \& Roediger-Schluga, T. (2006). The Determinants of Pharmaceutical R\&D Expenditures: Evidence from Japan. Review of Industrial Organization, 28(2), 145-164. http://dx.doi.org/10.1007/s11151-006-0010-z 
Malmberg, C. (2008). R\&D and financial systems: the determinants of R\&D expenditures in the Swedish pharmaceutical industry. CIRCLE Electronic Working Paper Series, Paper no. 2008/01.

Mansfield, E. (1964). Industrial Research and Development Expenditures: Determinants, Prospects, and Relation to Size of Firm and Inventive Output. The Journal of Political Economy, 72(4), 319-340. http://dx.doi.org/10.1086/258914

Nadiri I. M. (1979). Contributions and Determinants of Research and Development Expenditures in the U. S. Manufacturing Industries. WP NO. 79-16, New York University.

Romer, P. M. (1986). Increasing Returns and Long-Run Growth. Journal of Political Economy, 94(5), 1002-1037. http://dx.doi.org/10.1086/261420

Romer, P. M. (1990). Endogenous Technological Change. Journal of Political Economy, 98(5), S71-102. http://dx.doi.org/10.1086/261725

Vecchi M., Barrel R., Becker B., Schmidt-Ehmcke J., \& Stephan A. (2007). The Determinants of Investment in Industrial Research and Development in the United Kingdom and in Germany. Anglo-German Foundation for the Study of Industrial Society.

Wang, E. C. (2010). Determinants of R\&D investment: The Extreme-Bounds-Analysis approach applied to 26 OECD countries. Research Policy, 39, 103-116. http://dx.doi.org/10.1016/j.respol.2009.11.010

Waterson, M., \& Lopez, A. (1983). The determinants of research and development intensity in the UK. Applied Economics, 15, 379-391. http://dx.doi.org/10.1080/00036848300000008

\section{Appendix}

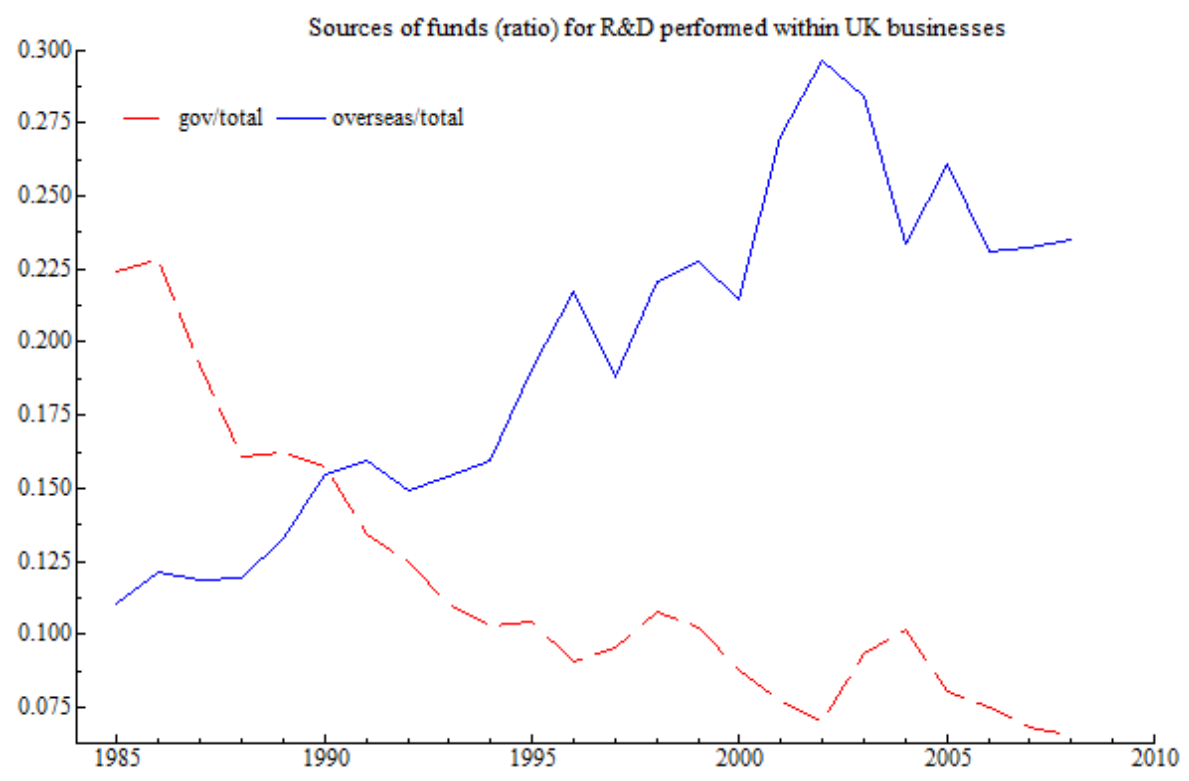

Figure 3. Proportion of public and foreign fund in $R \& D$ investment

\section{Copyrights}

Copyright for this article is retained by the author(s), with first publication rights granted to the journal.

This is an open-access article distributed under the terms and conditions of the Creative Commons Attribution license (http://creativecommons.org/licenses/by/3.0/). 